\section{Evolution of the deaths registry system in Brazil: associations with changes in the mortality profile, under-registration of death counts, and ill-defined causes of death}

\author{
A evolução do sistema de registro de mortalidade \\ no Brasil: mudanças no perfil de mortalidade, \\ cobertura do registro de óbitos e as causas \\ mal definidas de morte
}

\author{
La evolución del sistema de registro de mortalidad \\ en Brasil: cambios en el perfil de mortalidad, \\ subregistro de defunciones y causas mal \\ definidas de muertes
}

\begin{abstract}
This paper examines the spatial pattern of illdefined causes of death across Brazilian regions, and its relationship with the evolution of completeness of the deaths registry and changes in the mortality age profile. We make use of the Brazilian Health Informatics Department mortality database and population censuses from 1980 to 2010. We applied demographic methods to evaluate the quality of mortality data for 137 small areas and correct for under-registration of death counts when necessary. The second part of the analysis uses linear regression models to investigate the relationship between, on the one hand, changes in death counts coverage and age profile of mortality, and on the other, changes in the reporting of ill-defined causes of death. The completeness of death counts coverage increases from about $80 \%$ in 1980-1991 to over 95\% in 2000-2010 at the same time the percentage of ill-defined causes of deaths reduced about 53\% in the country. The analysis suggests that the government's efforts to improve data quality are proving successful, and they will allow for a better understanding of the dynamics of health and the mortality transition.
\end{abstract}

Mortality; Cause of Death; Information Systems
Everton Emanuel Campos de Lima 1,2 Bernardo Lanza Queiroz ${ }^{3}$

\section{Resumo}

Este artigo analisa o padrão espacial das causas mal definidas de morte no Brasil e sua relação com a evolução do registro de óbitos e as mudanças no perfil etário da mortalidade. Usamos o banco de dados de mortalidade disponível no Departamento de Informática do SUS e os censos demográficos de 1980 a 2010, e aplicamos métodos demográficos para avaliar a qualidade dos dados de mortalidade por 137 pequenas áreas e corrigir o sub-registro de óbitos. A segunda parte da análise utiliza modelos de regressão linear para investigar a relação entre as mudanças na cobertura do registro de óbitos e o perfil etário da mortalidade em relação às mudanças no registro de causas mal definidas. Os resultados mostram que a cobertura do registro de óbito no Brasil saltou de 80\% em 1980-1991 para mais de 95\% em 2000-2010. Ao mesmo tempo, o porcentual de causas mal definidas de mortes reduziu cerca de $53 \%$ no país. A análise sugere que os esforços do governo para melhorar a qualidade de dados no Brasil são bem sucedidos, e que irá permitir uma melhor compreensão da dinâmica da saúde e da transição da mortalidade no país.

Mortalidade; Causas de Morte; Sistemas de Informação 


\section{Introduction}

In Brazil, mortality estimates and the knowledge of levels and trends of mortality are limited by the quality of data $1,2,3,4$. The most common problems faced are incomplete coverage of vital registration systems, errors in age declaration for both population and death counts, and lack of information on causes of deaths 1,4,5. By international standards, Brazil is characterized by high levels of ill-defined causes of death ${ }^{6}$ and regular levels of death counts registration 7,8,9,10. Information on causes of death is of fundamental importance because they provide subsidies to assess the health status of populations and for planning, monitoring and health evaluation, especially at sub-national levels 6,11. The high concentration of ill-defined causes of death reflects the lack of access to basic health services and the quality of healthcare 12 and is also considered an indicator for assessing the quality of the death registration system $1,6,11$. If the relative number of ill-defined causes of death is high, it will then harm the study of epidemiological and health transitions, especially across regions and over time 12 .

In the last three decades, the Brazilian government has made significant investments to improve the coverage of death records and quality of death counts registration 13,14. Although the vital registration system has shown clear signs of improvement in recent years, the quality of death counts coverage and information on causes of death varies widely by region 1,3 . In this context, this paper aims to examine the spatial pattern of ill-defined causes of death across Brazilian regions, and its relationship with the evolution of completeness of the deaths registry and changes in the mortality age profile.

This study rests on two working hypotheses: (i) that there is an association between improvements in death counts registration and declining percentage of deaths reported as ill-defined; and (ii) that population aging and concentration of deaths at older ages are associated with increases in the percentage of deaths reported as ill-defined. We argue that regions with better death counts coverage present better quality reports on causes of death and, in other regions, as mortality coverage improves, the percentage of ill-defined causes decreases. However the quality of the cause of death registry is hampered by the concentration of deaths in ages 65 and above. Thus, the main objective of the present study is to test these two hypotheses by analyzing the temporal evolution of the quality of the causes of death registry and its association with the evolution of distribution of deaths above the age of 65 and coverage of death counts between 1980 and 2010 .

\section{Methods}

\section{Data}

We make use of the mortality database available at the Brazilian Health Informatics Department (DATASUS. http://www2.datasus.gov.br/DA TASUS/index.php?area $=0205$, accessed on 22/ Oct/2012). The data are collected by age, sex and cause of death at the municipality level. Population by age and sex comes from the national household census conducted by the Brazilian Institute of Geography and Statistics (IBGE) in 1980, 1991, 2000 and 2010. The deaths and ill-defined death causes information are provided by the ninth and tenth revision of the International Classification of Diseases (ICD-10).

We aggregated municipalities by comparable small areas, using the IBGE definition of comparable meso-regions. These regions are constructed utilizing regional and socioeconomic similarities. The meso-regions serve only for statistical purpose; therefore, they do not represent a political or administrative entity. The main advantage of working with these comparable areas is that they have not changed their boundaries over the period of analysis. Thus, we are able to follow and study 137 small areas between 1980 and 2010.

\section{Coverage of death registration}

To evaluate the coverage of reported deaths we use traditional demographic methods, called Death Distribution Methods (DDM) henceforth $15,16,17$. The DDM are commonly used to estimate adult mortality in a non-stable population and analyze mortality data quality in intercensal periods $15,18,19$. There are three alternative approaches. The Synthetic Extinct Generations (SEG) method uses age-specific growth rates to convert an observed distribution of deaths by age into the corresponding stationary population age distribution. Since in a stationary population the deaths above each age $\mathrm{x}$ are equal to the population aged $x$, the deaths in the stationary population above age $\mathrm{x}$ provide an estimate of the population of age $x$. The completeness of death registration relative to population is estimated by the ratio of the death-based estimate of population aged $x$ to the observed population aged $x$. The General Growth Balance (GGB) method is derived from the basic demographic balancing equation, which identifies the growth rate of the population as equal to the difference between its entry rate and exit rate. This holds for openended age segments $x+$, and in a closed population the only entries are through birthdays at age $x$. The entry rate $x+$ minus the growth rate 
$x+$ thus provides a residual estimate of the death rate $x+$. If the residual estimate can be calculated from population data from two population censuses and compared to a direct estimate using the recorded deaths, the completeness of death recording relative to population recording can be estimated. It is argued that the combination of SEG and GGB might be more robust than either one individually. The combined method consists of first applying GGB to estimate any changes in census coverage $(\mathrm{k} 1 / \mathrm{k} 2)$, using the estimate to adjust one or the other census to make the two consistent, and then applying SEG using the adjusted instead of the reported population data $15,20,21$. They make several strong assumptions: (i) that the population is closed to migration; (ii) that the completeness of recording of deaths and population are constant by age; and (iii) that ages of the living and the dead are reported without error. There is a large body of literature on the methods 15,16,17, but for reasons of space they will not be discussed in detail here.

The assumption that the population is closed to migration is important to Brazilian regions, since the country is marked by significant migration flows between its regions 22 . We follow the approach proposed by Hill et al. 15 by taking the average of the estimates produced by the combination of the general growth balance method with the synthetic extinct generation to provide the best fit for the model. The DDM method uses information on deaths and growth rates accumulated above a series of ages $x$. If there is some age $x$ above which net migration is negligible, the performance of the methods above that age will be unaffected 15,20 . We use the age range $30+$ to $65+$ as suggested elsewhere 15,21 to avoid possible problems regarding migration and to overcome limitations as a result of old age reporting errors (referring to age declaration). The inverse of estimated coefficient is used to adjust the number of deaths by age and provide better estimates of mortality and life expectancy 15.

The second part of the analysis studies the changes in the quality of mortality data between the periods of 1991-2000 and 2000-2010. We investigate the relationship between the changes in the percentage of ill-defined causes of death and changes in the percentage of completeness of death counts coverage and in the percentage of deaths above the age of 65 . We study this relationship after controlling for other confounding effects such as regional and socioeconomic differences. Region plays an important role in the model, since Brazil is marked by large regional differences in terms of development and socioeconomic indicators 23. This variable also captures other unobserved variables that could affect the quality of health data. The model has the following specification (1) and it is estimated for each period and for males and females separately.

(1) $\Delta Y_{\text {ill-defined.mortality }}=\Delta \beta_{\text {coverage }}+\Delta \beta_{\text {elderly.mortality }}$ $+\Delta \beta_{\text {household.income }}+\beta_{\text {region }}+\varepsilon$

\section{Results}

\section{Descriptive analysis}

Figure 1 shows the evolution of death counts coverage for each intercensal period across mesoregions in Brazil. Table 1 shows the evolution of the percentage of deaths recorded as ill-defined, death counts coverage for each intercensal period and percentage of deaths above the age of 65 in the country and by region over time, for each census year. The spatial trends and levels are very similar for both sexes, so for simplicity we only show results for males.

The results indicate a reduction in the overall levels of deaths registered as ill-defined in Brazil. From 1991 to 2010, the number of mesoregions with more than $20 \%$ of deaths registered as ill-defined reduced significantly across the country. Most of these areas were located in the Northern and Northeastern parts of the country. Most importantly, the pace of decline in the percentage of ill-defined causes of death is significant. Table 1 shows that in some areas the percentage of ill-defined causes declined from $72 \%$ of total causes to less than $30 \%$ over the period of analysis. The percentage of ill-defined death records is still high for international standards, but recent investments led to a clear improvement in data quality. In recent years, one can observe clusters of ill-defined death causes in the less developed Northern and Northeastern regions and better data quality in the South and Southeast regions.

Completeness of death counts increased from $80 \%$ in $1980-1991$ to $95 \%$ in $2000-2010$, but a large regional variation still persists in a similar pattern to the distribution of ill-defined causes of death. Figure 1 shows improvements in death counts registration across Brazil, and more specifically in the less developed parts of the country. In the first intercensal period, 1980 to 1991, for most of Brazil completeness of death counts registration ranged from 55 to $85 \%$. It is observed that some mesoregions in the South and Southeast presented good data quality (95 to $100 \%$ completeness of death counts). Spatial heterogeneity gradually reduced in the following intercensal periods (1991-2000 and 2000-2010). In the second period of analysis (1991-2000) it 
Figure 1

Evolution of the quality of mortality data in males. Brazil, 1980-2010.

1a) $1980-1991$

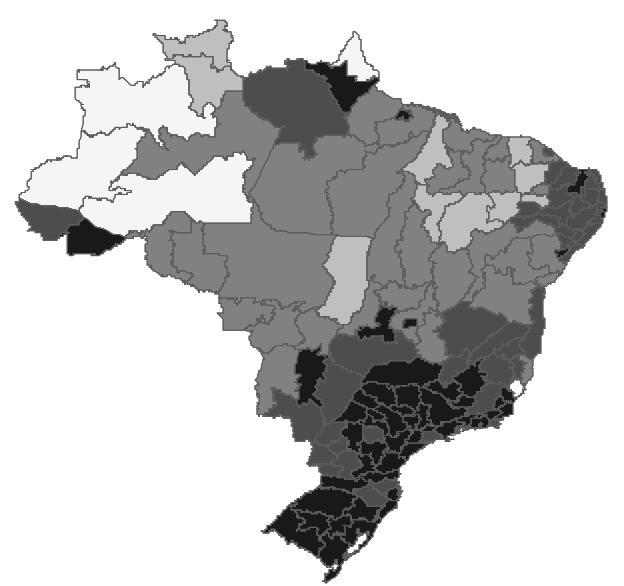

1b) $1991-2000$

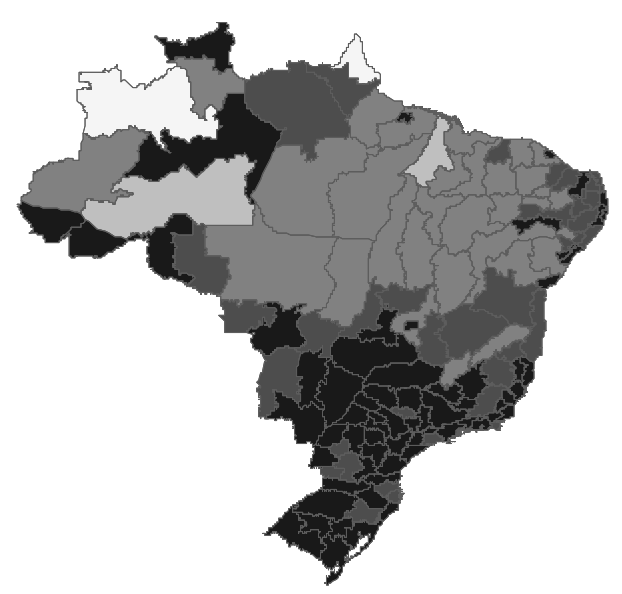

1c) $2000-2010$

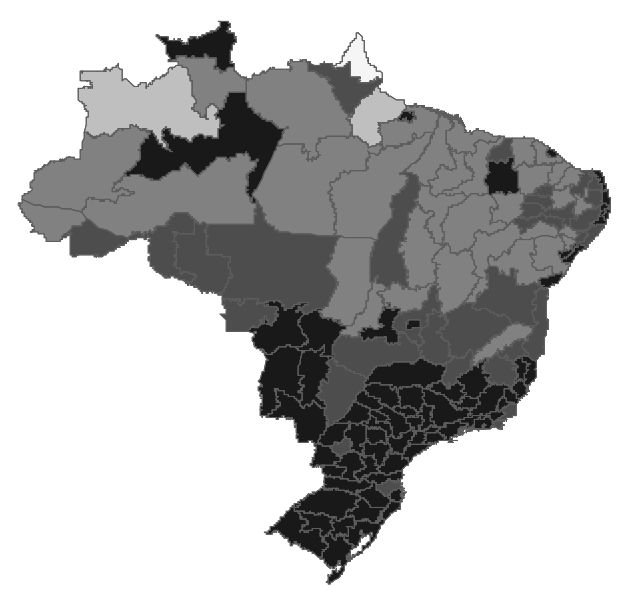

Death counts coverage (\%)

$\square[5,35)$

$\square[35,55)$

$[55,85)$

$[85,95)$

$\square[95,100]$

Source: Brazilian Health Informatics Department (DATASUS), 2012 and population censuses (1980, 1991, 2000, 2010) of the Brazilian Institute of Geography and Statistics (IBGE). 
Descriptive statistics of the quality of mortality data by mesoregions, in males. Brazil and regions, 1980 to 2010 .

\begin{tabular}{|c|c|c|c|c|c|c|c|c|c|}
\hline \multirow[t]{2}{*}{ Regions } & \multicolumn{3}{|c|}{$\begin{array}{l}\text { Percentage of ill-defined } \\
\text { mortality }\end{array}$} & \multicolumn{3}{|c|}{ Degree of completeness death counts } & \multicolumn{3}{|c|}{$\begin{array}{l}\text { Percentage of deaths above age } \\
\qquad 65+\end{array}$} \\
\hline & 1991 & 2000 & 2010 & $1980-1991$ & $1991-2000$ & $2000-2010$ & 1991 & 2000 & 2010 \\
\hline \multicolumn{10}{|l|}{ Brazil } \\
\hline Minimum & 0.0 & 2.0 & 0.7 & 6.0 & 13.0 & 32.0 & 6.2 & 21.2 & 16.8 \\
\hline Mean & 27.5 & 19.9 & 8.5 & 83.2 & 88.6 & 89.7 & 38.8 & 42 & 46.8 \\
\hline Maximum & 72.1 & 61.3 & 27.9 & 100.0 & 100.0 & 100.0 & 58.7 & 56.4 & 60.0 \\
\hline Total of areas & 137 & 137 & 137 & 137 & 137 & 137 & 137 & 137 & 137 \\
\hline \multicolumn{10}{|l|}{ North } \\
\hline Minimum & 0.0 & 6.6 & 2.3 & 6.0 & 13.0 & 32.0 & 6.2 & 21.2 & 16.8 \\
\hline Mean & 30.4 & 25.6 & 13.5 & 64.8 & 75.1 & 76.1 & 26.2 & 31.4 & 35.1 \\
\hline Maximum & 72.1 & 61.3 & 25.7 & 100.0 & 100.0 & 100.0 & 41.6 & 43.5 & 45.5 \\
\hline Total of areas & 20 & 20 & 20 & 20 & 20 & 20 & 20 & 20 & 20 \\
\hline \multicolumn{10}{|l|}{ Northeast } \\
\hline Minimum & 8.9 & 2.5 & 1.5 & 36.0 & 51.0 & 56.0 & 30.9 & 32.2 & 35.4 \\
\hline Mean & 48.9 & 31.9 & 8.1 & 76.3 & 83.5 & 84.6 & 44.8 & 44.0 & 47.2 \\
\hline Maximum & 71.5 & 54.4 & 27.9 & 100.0 & 100.0 & 100.0 & 58.7 & 56.4 & 60.0 \\
\hline Total of areas & 42 & 42 & 42 & 42 & 42 & 42 & 42 & 42 & 42 \\
\hline \multicolumn{10}{|l|}{ South } \\
\hline Minimum & 2.5 & 2.0 & 2.5 & 88.0 & 90.0 & 91.0 & 33.8 & 38.2 & 41.7 \\
\hline Mean & 13.2 & 7.5 & 5.3 & 95.4 & 96.3 & 97.7 & 41.3 & 47.1 & 51.4 \\
\hline Maximum & 27.5 & 17.2 & 13.3 & 100.0 & 100.0 & 100.0 & 50.3 & 53.8 & 58.2 \\
\hline Total of areas & 37 & 37 & 37 & 37 & 37 & 37 & 37 & 37 & 37 \\
\hline \multicolumn{10}{|l|}{ Southeast } \\
\hline Minimum & 2.4 & 2.8 & 0.7 & 79.0 & 79.0 & 79.0 & 30.8 & 35.7 & 40.9 \\
\hline Mean & 15.6 & 15.1 & 9.5 & 95.5 & 96.0 & 96.9 & 40.2 & 44.6 & 50.9 \\
\hline Maximum & 42.8 & 37.5 & 24.4 & 100.0 & 100.0 & 100.0 & 47.8 & 53.5 & 58.7 \\
\hline Total of areas & 23 & 23 & 23 & 23 & 23 & 23 & 23 & 23 & 23 \\
\hline \multicolumn{10}{|l|}{ Central } \\
\hline Minimum & 1.9 & 3.7 & 1.0 & 54.0 & 74.0 & 83.0 & 16.8 & 26.4 & 32.4 \\
\hline Mean & 14.7 & 9.3 & 5.1 & 77.5 & 90.9 & 91.3 & 31.8 & 36.4 & 43.8 \\
\hline Maximum & 31.0 & 18.0 & 11.9 & 100.0 & 100.0 & 100.0 & 41.0 & 44.1 & 50.4 \\
\hline Total of areas & 15 & 15 & 15 & 15 & 15 & 15 & 15 & 15 & 15 \\
\hline
\end{tabular}

Source: Brazilian Health Informatics Department (DATASUS), 2012 and population censuses (1980, 1991, 2000, 2010) of the Brazilian Institute of Geography and Statistics (IBGE).

is observed that data quality improved to other regions such as the Central, where Brazil's capital is located, and in some regions in the Northeast. Very poor data quality was still observed in some states, for example, in Maranhão and Piauí states and in most states in the Northern region.

In the most recent period, 2000 to 2010, the completeness of death counts coverage varies from $32 \%$ in the worst area (located in the Northern state of Amapá) to $100 \%$ in several mesoregions of the South and Southeast and in many parts of the Northeast coast and Central mesoregions. The estimated coefficients indicate that a large number of regions in Brazil do not collect complete information on the number of deaths that occurred in the region, this leads to an overestimation of life expectancy and might mislead public health policies, although clear signs of improvement were observed all over the country.

Finally, the demographic and epidemiological transitions combined lead to an increase in the percentage of deaths above the age of 65, for males and females. In 1991, parts of the South and Southeast and most of the Northeast had a higher concentration of deaths (more than 55\%) among individuals above the age of 65 compared 
to other parts of the country. In 2010, it is observed that in addition to those regions, other mesoregions in the Central, Northeast and North of the country also present a large concentration of deaths above 65 .

A similar aging process has been observed in other countries 24 and could have a direct impact on the quality of mortality data across Brazilian regions. Some authors identify that a significant percentage of ill-defined deaths occurred at home without an attending physician making it more complicated to identify the correct cause of death 1,25 . Other scholars pointed out that, in the past today's elderly were exposed to curative medicine and not to health promotion and disease prevention 26 . Therefore, due to the lack of longitudinal care of the elderly, it is not possible for physicians to always know what the factors involved in the elderly's death were, nor even, sometimes, the main cause.

The empirical evidence presented above indicates that as the population ages and older individuals live alone 25,27 there will be an increasing demand for accessing the quality of death information for older individuals.

\section{Regression analysis}

We then look at how variations in the percentage of ill-defined causes of deaths are associated with changes in the completeness of death counts coverage and the age pattern of mortality (deaths over age 65). Tables 2 and 3 show the results of the regression models for each intercensal period for males and females, respectively.

From 1991 to 2000, the results indicate that an increase in $1 \%$ in the completeness of death counts coverage for males is associated with a $0.24 \%$ reduction in the percentage of ill-defined causes of deaths. The result is statistically significant at the $1 \%$ level. Thus, improvements in data collection of death counts seems to occur alongside enhancements in reports of death causes. For females, the association is also valid (coefficient of -0.16), but somewhat weaker and statistically significant at the $10 \%$ level. We argue that this difference is related to the historically low levels of death count completeness for females in Brazil 1,3,28. In the more recent periods, we do not find any significant association between changes in the completeness of death counts coverage and quality of causes of death information for both sexes. It seems that in the more recent period, changes in the declaration of causes of death are more closely associated with changes in the mortality age profile.

In relation to the concentration of death at elderly ages, the results point to a positive association between the percentage of deaths above the age of 65 and the percentage of deaths re corded as ill-defined. For males, an increase in $1 \%$ in concentration of deaths above 65 is associated with a $0.61 \%$ increase in the number of ill-defined death causes from 1991 to 2000 . In the last decade, the strength of this relationship is reduced, and a $0.55 \%$ increase of ill-defined deaths

Linear regression models of the variation of percentage of ill-defined deaths, in males. Brazil, 1991-2000 and 2000-2010.

\begin{tabular}{|c|c|c|c|}
\hline Variation between 1991 and 2000 & Coefficient & Variation between 2000 and 2010 & Coefficient \\
\hline Intercept & 13.77 * & Intercept & -12.32 * \\
\hline $\begin{array}{l}\text { Variation in death counts coverage }-1980 / 1991 \\
\text { to } 1991 / 2000\end{array}$ & $-0.24 *$ & $\begin{array}{l}\text { Variation in death counts coverage }-1991 / 2000 \text { to } \\
2000 / 2010\end{array}$ & 0.13 \\
\hline $\begin{array}{l}\text { Variation in the percentages of deaths aged } 65+ \\
\text { from } 1991 \text { to } 2000\end{array}$ & $0.61 *$ & $\begin{array}{l}\text { Variation in the percentages of deaths aged } 65+\text { from } 2000 \\
\text { to } 2010\end{array}$ & 0.55 * \\
\hline Variation in income per capita from 1991 to 2000 & $0.04 * \star$ & Variation in income per capita from 2000 to 2010 & $0.03 * \star \star$ \\
\hline South/Southeast (reference) & & South/Southeast (reference) & \\
\hline North & 4.84 & North & $-4.70 * \star \star$ \\
\hline Northeast & -4.22 & Northeast & $-16.58 *$ \\
\hline Central & 0.99 & Central & -1.03 \\
\hline
\end{tabular}

Source: Brazilian Health Informatics Department (DATASUS), 2012 and population censuses (1980, 1991, 2000, 2010) of the Brazilian Institute of Geography and Statistics (IBGE).

${ }^{*} \mathrm{p}<0.01$

** $p<0.05$

$\star \star \star p<0.10$ 
Linear regression models of the variation of percentage of ill-defined deaths, in females. Brazil, 1991-2000 and 2000-2010.

\begin{tabular}{|c|c|c|c|}
\hline Variation between 1991 and 2000 & Coefficient & Variation between 2000 and 2010 & Coefficient \\
\hline Intercept & $-11.81 *$ & Intercept & -8.28 ** \\
\hline $\begin{array}{l}\text { Variation in death counts coverage }-1980 / 1991 \text { to } \\
1991 / 2000\end{array}$ & $-0.16^{\star \star \star}$ & $\begin{array}{l}\text { Variation in death counts coverage }-1991 / 2000 \text { to } \\
2000 / 2010\end{array}$ & 0.19 \\
\hline $\begin{array}{l}\text { Variation in the percentages of deaths aged } 65+ \\
\text { from } 1991 \text { to } 2000\end{array}$ & $0.32 * \star \star$ & $\begin{array}{l}\text { Variation in the percentages of deaths aged } 65+\text { from } \\
2000 \text { to } 2010\end{array}$ & 0.03 \\
\hline Variation in income per capita from 1991 to 2000 & 0.03 & Variation in income per capita from 2000 to 2010 & 0.02 \\
\hline South/Southeast (reference) & & South/Southeast (reference) & \\
\hline North & 7.12 ** & North & -8.79 * \\
\hline Northeast & $-7.19 * \star$ & Northeast & -21.84 * \\
\hline Central & 1.16 & Central & 0.09 \\
\hline
\end{tabular}

Source: Brazilian Health Informatics Department (DATASUS), 2012 and population censuses (1980, 1991, 2000, 2010) of the Brazilian Institute of Geography and Statistics (IBGE).

* $\mathrm{p}<0.01$;

** $\mathrm{p}<0.05$

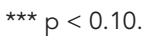

is associated with a $1 \%$ increase in the concentration of deaths above the age of 65 . The results for males are significant at the $1 \%$ level. For females, however, we find no evidence that an increase in the percentage of deaths over the age of 65 is associated with the quality of causes of death information. These results are probably related to the different way that males and females use health services in Brazil 29,30: since females have a longer and more regular medical history, it is possible that health workers have more reliable information for determining their cause of death, than is the case for males. Also, males tend to die more often outside health facilities, thereby reduces the chance of determining the cause of death ${ }^{31}$.

The results also seem to indicate that changes in data quality in the Northeast and North regions have been slower than changes observed in other parts of the country, and regional differences in both periods are more pronounced for females than for males. Furthermore, the Central region does not show significant statistical differences compared to the South and Southeast regions in both periods.

It is important to mention that socioeconomic developments do not have a strong association with the observed improvements in the past two decades. It seems governmental and administrative investments in collecting death records are the main reason for the recent improvements in the Brazilian system for death statistics.

\section{Discussion}

Death counts and causes of death data are fundamental information to plan public health measures in most countries, and the evaluation of data quality is an important step to achieve high levels of quality 11. Previous studies have shown improvements in the vital registration system in Brazil, but to the best of our knowledge, this is the first study to investigate the issue covering the last three decades and analyzing smaller areas (mesoregions). The main finding of this paper is that there has been an improvement in the collection of mortality data in Brazil. The completeness of death counts coverage increases from about $80 \%$ in $1980-1991$ to over $95 \%$ in 2000 2010, while at the same time the percentage of illdefined causes of deaths was reduced by about $53 \%$ in the country. There are still large regional differences; the South and Southeast have much better data quality than the rest of the country. However, we observed clear improvements in the quality of data in the less developed regions of Brazil 1. However, contrary to what could be expected, the improvements in data quality are not closely associated with regional socioeconomic indicators.

The observed improvements seem to be very closely associated with investments in the public health care system and administrative procedures to collect vital statistics 1,32,33. Thus, the quality of mortality data for adults seems to have expressively improved through the years and 
across many regions. At the same time, we find that in areas where mortality is concentrated at older ages, the percentage of deaths registered as ill-defined also increases.

Britton 34 argues that the high proportion of ill-defined causes may be due to a greater difficulty in selecting the true cause of death among the elderly. Due to the aging process, the elderly population starts to present many connected morbidities 27 and several chronic degenerative diseases such as cancer, hypertension, diabetes and other diseases of the circulatory system, and hence the decision about the real underlying causes become more complex in these cases 34 .

Other authors also emphasize the role of the physicians responsible for filling out death certificates. According to them, the most relevant factor that contributes to a greater proportion of ill-defined deaths at old ages in Brazil is an inadequate report by the physicians of the actual causes of death (underlying, associated and complications) in the death certificates 25,33 . It should be highlighted that the tradition of curative medicine in Brazil - and the lack of preventive and continuous health service 26 - sometimes makes it difficult for physicians to judge accurately the main cause of death in the elderly.

These results lead to a discussion about how ill-defined mortality can be seen as an indicator of data quality. Previous studies showed that a higher proportion of ill-defined causes of death are found among the elderly and small children, are more concentrated in less-developed regions of the country and that most of them happened outside a health facility 1,25,31,33. We should expect that the number of ill-defined causes of death would decrease as improvements in diseasediagnosis develop over time. On the one hand, as senescence progresses, new diseases might appear and more investments in the diagnostics processes might be necessary. On the other hand, some authors argue that the concept of senescence could be accepted as a cause of death for the very old and, therefore, should not be considered as indicative of poor quality mortality data 35 . In this case, ensuring the quality of mortality data for the elderly will require more care and investments in the health care of this particular age group, especially because these deaths could occur outside a health facility 1 . Furthermore, some scholars also advocate that, in order to have an accurate epidemiological profile for the elderly population, we should invest in more methods and not rely only on death certificates 25 .

Although the study has important findings for the planning of public health measures in Brazil, the results should be viewed with caution. The main limitation is the application of the death distribution methods for small areas 15,36. The methods make strong assumptions about closed populations and the constant quality of declarations across ages that is more limited for smaller areas. We believe that this is an important area for future research. In this paper, we have followed similar approaches performed by others 15,36 and we considered them to be reasonable based on the relative pattern of completeness across regions. Despite these limitations, we believe that the study gives important insights about the evolution of data quality in Brazil and indicates that the South, Southeast and Central regions have good mortality data and the North and Northeast have shown consistent improvements in recent years.

The analysis suggests that efforts made by central and local governments to improve data quality in Brazil 32,33 are showing signs of success, and that they will allow a better understanding of the dynamics of health and mortality transition in Brazil. It is clear, however, that more investments are necessary in some parts of the country that are still lagging behind in this area. It is important that there be continuous study and evaluation of data quality, especially for small areas and investments for all administrative levels to improve health information in Brazil. However, further analysis should also be done to understand better what is happening at the local level, since ill-defined causes of death records are considered to be an indicator of poor data quality and health services, and workers in the health sector might be induced to report any cause of death to avoid reporting the event as ill-defined. In this area, continuous investments in the Brazilian Family Health Program 32,33 could have important impacts on the improvement of mortality data quality in Brazil since its personnel work closely with the community and accompany the health status of several individuals under their jurisdiction. 


\section{Resumen}

Este artículo examina el patrón espacial de causas mal definidas de muerte en todas las regiones brasileñas, $y$ su relación con la evolución de la totalidad de muertes por registro, además de con los cambios producidos en el perfil de edad de mortalidad. Usamos la base de datos de mortalidad DATASUS y censos de población de 1980 a 2010. Se aplicaron métodos demográficos para evaluar la calidad de los datos de mortalidad en 137 áreas pequeñas y se realizaron revisiones para el recuento de las muertes por subregistro. En la segunda parte del análisis se emplean modelos de regresión lineal para investigar la relación entre los cambios en la cobertura de registro de muerte y el perfil de edad de mortalidad, respecto a los cambios en la presentación de causas mal definidas de la muerte. Los datos resultantes informan de un aumento en la cobertura del $80 \%$ al $95 \%$ y una reducción de un 53\% en las causas mal definidas de 1980 a 2010. El análisis sugiere que los esfuerzos del gobierno para mejorar la calidad de los datos son exitosos, y permitirán una mejor comprensión de la dinámica de la salud y la transición de mortalidad.

Mortalidad; Causas de Muerte; Sistemas

de Información

\section{Contributors}

E. E. C. Lima and B. L. Queiroz defined the research theme, applied death distribution methods, interpreted the results and wrote the paper. All authors have contributed to, seen and approved the manuscript.

\section{Acknowledgments}

B. L. Queiroz is grateful for financial support from FAPEMIG (Pesquisador Mineiro Program) and CNPq.

\section{References}

1. França EB, Abreu DMX, Rao C, Lopez A. Evaluation of cause-of-death statistics for Brazil, 2002-2004. Int J Epidemiol 2008; 37:891-901.

2. França EB, Rao C, Abreu DMX, Souza MFM, Lopez AD. Comparison of crude and adjusted mortality rates from leading causes of death in northeastern Brazil. Rev Panam Salud Pública 2012; 31:275-82.

3. Paes NA. Avaliação da cobertura dos registros de óbitos dos estados brasileiros em 2000. Rev Saúde Pública 2005; 39:882-90.

4. Paes NA. Qualidade das estatísticas de óbitos por causas desconhecidas dos estados brasileiros. Rev Saúde Pública 2007; 41:436-45.
5. Cavalini LT, Ponce de Leon ACM. Correção de subregistro de óbitos e proporção de internações por causas mal definidas. Rev Saúde Pública 2007; 41:85-93.

6. Mathers C, Doris MF, Mie I, Chalapati R, Alan DL. Counting the dead and what they died from: assessment of the global status of cause of death data. Bull World Health Organ 2005; 83:171-7.

7. Luy M. A classification of the nature of mortality data underlying the estimates for the 2004 and 2006 United Nations' World Population Prospects. Comparative Population Studies 2010; 35:315-34. 
8. Setel P, MacFarlane SB, Szreter S, Mikkelsen L, Jha P, Stout $S$, et al. Who counts? 1 - A scandal of invisibility: making everyone count by counting everyone. Lancet 2007; 370:1569-77.

9. Pan-American Health Organization. Health situation in the Americas: basic health indicators 2010. Washington DC: Pan-American Health Organization; 2010.

10. The PLoS Medicine Editors. Can we count on global health estimates? PLoS Med 2010; 7:e1001002.

11. Rao C, Lopez AD, Yang G, Begg S, Ma J. Evaluating national cause-of-death statistics: principles and application to the case of China. Bull World Health Organ 2005; 83:618-25.

12. AbouZhar C, Boerma T. Health information systems: the foundations of public health. Bull World Health Organ 2005; 83:578-83.

13. Ministério da Saúde. Sistemas de informação: SIM e SINASC. In: Anais 2a Expoepi - Mostra Nacional de Experiências Bem-sucedidas em Epidemiologia, Prevenção e Controle de Doenças. Brasília: Ministério da Saúde; 2003. p. 31-6.

14. Ministério da Saúde. Monitoramento da acurácia dos sistemas de informações sobre mortalidade e nascidos vivos. In: Anais 3a Expoepi - Mostra Nacional de Experiências Bem-sucedidas em Epidemiologia, Prevenção e Controle de Doenças. Brasília: Ministério da Saúde; 2004. p. 173-80.

15. Hill K, You D, Choi Y. Death distribution methods for estimating adult mortality: sensitivity analysis with simulated data errors. Demogr Res 2009; 21:235-54.

16. Dorrington RE. General growth balance. In: Moultrie TA, Dorrington RE, Hill AG, Hill KH, Timæus IM, Zaba B, editors. Tools for demographic estimation. Paris: International Union for the Scientific Study of Population; 2012. http://demographices timation.iussp.org/content/general-growth-bal ance (accessed on 15/Sep/2012).

17. Dorrington RE. Synthetic extinct generations. In: Moultrie TA, Dorrington RE, Hill AG, Hill KH, Timæus IM, Zaba B, editors. Tools for demographic estimation. Paris: International Union for the Scientific Study of Population; 2012. http://demo graphicestimation.iussp.org/content/syntheticextinct-generations (accessed on 15/Sep/2012).

18. Timaeus IM. Measurement of adult mortality in less developed countries: a comparative review. Popul Index 1991; 57:552-68.

19. Hill K, Choi Y, Timeaus IM. Unconventional approaches to mortality estimation. Demogr Res 2005; 13:281-300.

20. Murray CJL, Rajaratnam JK, Marcus J, Laakso T, Lopez AD. What can we conclude from death registration? Improved methods for evaluating completeness. PLoS Med 2010; 7:e1000262.

21. Hill K, Queiroz B. Adjusting general growth method to migration. Rev Bras Estud Popul 2010; 27:7-20.

22. Barbieri AF, Domingues E, Queiroz BL, Ruiz RM, Rigotti JI, Carvalho JAM, et al. Climate change and population migration in Brazil's Northeast: scenarios for 2025-2050. Popul Environ 2010; 31:344-70.
23. Azzoni C. Economic growth and regional income inequality in Brazil. Ann Reg Sci 2001; 35:133-52.

24. Canudas-Romo V. Mortality changes in the Iberian Peninsula in the last decades of the twentieth century. Population-E 2008; 63:319-44.

25. Mello JMHP, Laurenti R, Lima-Costa MF, Gotlieb SLD, Chiavegatto ADPF. A mortalidade de idosos no Brasil: a questão das causas mal definidas. Epidemiol Serv Saúde 2008; 17:271-81.

26. Castro BMMM, Telles JL. O cuidado do idoso no contexto familiar: percepção da equipe de saúde da família. Rev Bras Geriatr Gerontol 2010; 13:349-60.

27. Vasconcelos AMN. Causas múltiplas de morte: uma análise de padrões de mortalidade entre idosos. In: Anais do XIII Encontro Nacional de Estudos de População. http://www.abep.nepo. unicamp.br/docs/anais/pdf/2002/GT_SAU_ST35_ Vasconcelos_texto.pdf (cessado em 15/Sep/2012).

28. Paes NA, Albuquerque MEE. Avaliação da qualidade dos dados populacionais e cobertura dos registros de óbitos para as regiões brasileiras. Rev Saúde Pública 1999; 33:33-43.

29. Verbrugge LM, Wingard DL. Sex differentials in health and mortality. Women Health 1987; 12:103-45.

30. Travassos C, Viacava F, Pinheiro R, Alexandre B. Utilização dos serviços de saúde no Brasil: gênero, características familiares e condição social. Rev Panam Salud Pública 2002; 11:365-73.

31. Abreu DMX, Sakurai E, Campos LN. A evolução da mortalidade por causas mal definidas na população idosa em quatro capitais brasileiras, 19962007. Rev Bras Estud Popul 2010; 27:75-88.

32. Ministério da Saúde. Vigilância em saúde no SUS: fortalecendo a capacidade de resposta para velhos e novos desafios. Brasília: Ministério da Saúde; 2006.

33. França E, Campos D, Souza MF. Use of verbal autopsy in a national health information system: effects of the investigation of ill-defined causes of death on proportional mortality due to injury in small municipalities in Brazil. Popul Health Metr 2011; 9:39.

34. Britton M. Diagnostic errors discovered at autopsy. Acta Med Scand 1974; 196:203-10.

35. Alpérovitch A, Bertrand M, Jougla E, Vidal J-S, Ducimetière $\mathrm{P}$, Helmer $\mathrm{C}$, et al. Do we really know the cause of death of the very old? Comparison between official mortality statistics and cohort study classification. Eur J Epidemiol 2009; 24:669-75.

36. Queiroz BL. Estimating maternal mortality differentials using census data: experience in Honduras. J Popul Res 2011; 28:75-87.

Submitted on 23/Jul/2013

Final version resubmitted on $21 / \mathrm{Jan} / 2014$

Approved on 28/Jan/2014 